ISSN 0258-7122

Bangladesh J. Agril. Res. 36(4): 563-574, December 2011

\title{
HEAVY METAL LEVELS IN VEGETABLES WITH GROWTH STAGE AND PLANT SPECIES VARIATIONS
}

\author{
HABIB MOHAMMAD NASER ${ }^{1}$, SARMIN SULTANA ${ }^{2}$, NASHIR UdDIN MAHMUD ${ }^{3}$ \\ REBECA GOMES ${ }^{3}$ AND SHAMSUN NOOR ${ }^{3}$
}

\begin{abstract}
Field experiment was conducted to compare and investigate the concentration levels of heavy metals in leafy vegetables with growth stage and plant species variations on an experimental field near the net house of Soil Science Division, Bangladesh Agricultural Research Institute, Joydebpur, Gazipur, Bangladesh during November 2008 to January 2009. Seeds of spinach (Spinacia oleracea), red amaranth (Amaranthus tricolor) and amaranth (Amaranthus oleraseus) were sown on 14 November 2008. Plant and soil samples were collected at different growth stages, such as at 20, 30, 40, and 50 days after sowing (DAS). The concentrations of lead $(\mathrm{Pb})$, cadmium $(\mathrm{Cd})$, nickel $(\mathrm{Ni})$, cobalt $(\mathrm{Co})$, and chromium $(\mathrm{Cr})$ in plant increased with the age of the plant, but the increase was not linear. The rate of increase of concentration of these metals at 20 to 30 DAS was found lower than that at 30 to 40 DAS, except Cr. Heavy metal content gradually increased at the early growing stage and fall during later stages of growth. The significant differences $(P<0.01)$ were observed between the mean metal concentrations in the three vegetables species. The $\mathrm{Pb}$ and $\mathrm{Co}$ concentrations in amaranth were found higher compared to those found in spinach and red amaranth. Spinach exhibited higher levels of $\mathrm{Cd}$ and $\mathrm{Cr}$ than those of other vegetables. However, the three vegetables did not differ significantly in its $\mathrm{Ni}$ concentration. The order of heavy metal level in different vegetables was $\mathrm{Cd}<\mathrm{Co}<\mathrm{Pb}<\mathrm{Ni}<\mathrm{Cr}$. In vegetable species in respect of heavy metal concentration $\mathrm{Cd}, \mathrm{Ni}$, and $\mathrm{Cr}$ was highest in spinach and amaranth showed highest concentration in $\mathrm{Pb}$ and $\mathrm{Co}$. The highest correlation between soil-plant was found for $\mathrm{Cd}$, while the lowest for $\mathrm{Ni}$. Metal concentrations in the vegetables studied were found lower than the maximum allowable level in India but the concentrations of $\mathrm{Cd}$ and $\mathrm{Cr}$ were higher than the allowable levels set by the World Health Organization (WHO).
\end{abstract}

Key words: Vegetables, heavy metal, concentration, growth stage, plant species

\footnotetext{
${ }^{1}$ Senior Scientific Officer, Soil Science Division, Bangladesh Agricultural Research Institute (BARI), Gazipur-1701, ${ }^{2}$ Scientific Officer, Soil Science Division, BARI, Gazipur-1701, ${ }^{3}$ Scientific Officer, Soil Science Division, BARI, Gazipur-1701, ${ }^{4}$ Principal Scientific Officer, Soil Science Division, BARI, Gazipur-1701, ${ }^{5}$ Chief Scientific Officer \& Head, Soil Science Division, BARI, Gazipur-1701, Bangladesh.
} 


\section{Introduction}

Soil pollution by heavy metals is great concern to public health (Goyer, 1996). The source of heavy metal in plant is the environment in which they grow and their growth medium (soil) from which heavy metals are taken up by roots or foliage of plants (Okonkwo et al., 2005). Plants grown in polluted environment can accumulate heavy metals at high concentration causing serious risk to human health when consumed. Moreover, heavy metals are toxic because they tend to bioaccumulate in plants and animals, bioconcentrate in the food chain and attack specific organs in the body ((Akinola et al., 2006; Chatterjee and Chatterjee, 2000).

Vegetables constitute an important part of the human diet since there contain carbohydrates, proteins, as well as vitamins, minerals and heavy metals. Heavy metals are one of a range of important types of contaminants that can be found on the surface and in the tissue of fresh vegetables (Bigdeli and Seilsepour, 2008). A number of elements, such as lead (Pb), cadmium (Cd), nickel (Ni), cobalt (Co), chromium (Cr), Copper (Cu) and Selenium (Se) (IV) can be harmful to plants and humans even at quite low concentrations (Bowen, 1979). Soil pollution is caused by misuse of the soil, such as poor agricultural practices, disposal of industrial and urban wastes, etc. (Buchaver, 1973). Soil is also polluted through application of chemical fertilizers (like phosphate and $\mathrm{Zn}$ fertilizers), and herbicides (Demi rezen and Aksoy, 2004). Heavy metal accumulation in soils is of concern in agricultural production due to the adverse effects on food quality, crop growth (Ma et al., 1994; Msaky and Calvert, 1990; Fergusson, 1990) and environmental health.

Plant species have a variety of capacities in removing and accumulating heavy metals. So there are reports indicating that some plant species may accumulate specific heavy metals (Markert, 1993). The uptake of metals from the soil depends on different factors, such as their soluble content in it, soil pH, plant species, fertilizers, and soil type (Lubben and Sauerberck, 1991). Vegetables, especially leafy vegetables, accumulate higher amounts of heavy metals (Sharma and Kansal, 1986). Roots and leaves of herbaceous plants retain higher concentration of heavy metal than stems and fruits (Yargholi and Azimi, 2008). There are limited studies on heavy metal content at different growth stages of vegetables, the most studies focused on the status of metal content in edible parts of vegetables. And an investigation of the literature also shows a scarcity of data on comparison of metal content at different leafy vegetable species in Bangladesh. Therefore, the present study was undertaken (i) to compare and investigate the concentration levels of heavy metals ( $\mathrm{Pb}, \mathrm{Cd}, \mathrm{Ni}, \mathrm{Co}$, and $\mathrm{Cr}$ ) at different growth stages of the commonly grown leafy vegetables; (ii) to find out a growth stage, which stage is less content of heavy metals; and iii) to quantify the concentrations of heavy metal content by different vegetable species. 


\section{Materials and Method}

\subsection{Experimental field}

Experimental plots were set up on an experimental field near the net house of Soil Science Division, Joydebpur, Gazipur, Bangladesh during November 2008 to January 2009. The experimental field was top-dressed by foreign soil near about three years before. So, it is not represent the characteristics of Gazipur soils. Experimental plots consisted of three replicate rectangular areas $(5 \mathrm{~m} \times 2$ $\mathrm{m}$ ) for each leafy vegetable and each replicate was separated by $1 \mathrm{ft}$ buffer area which was left as barren. Seeds of spinach (Spinacia oleracea), red amaranth (Amaranthus tricolor) and amaranth (Amaranthus oleraseus) were sown on 14 November 2008. Fertilizers NPK were applied @ 75, 25, and 60 kg/ha from the source of Urea, triple super phosphate (TSP), and muriate of potash (MoP), respectively. Before fertilizer application and seeding initial soil sample (top soils, $0-15 \mathrm{~cm}$ ) was collected. Initial soil and fertilizers sample were analyzed in the laboratory.

\subsection{Plant and soil sample collection}

Plant and soil samples were collected at four growth stages of vegetables at 20, 30, 40, and 50 days after sowing. The samples were collected carefully using hand trowel to dig the soil around the plant and the plants were pulled out carefully, ensuring that no part of the root was lost. Plant samples were kept in separate polythene bags and properly labeled. Soil samples were collected at a depth of $0-15 \mathrm{~cm}$ from the same point of collecting plant samples. The samples were kept in polythene bags and labeled properly. The plant and soil samples were analyzed in the laboratory.

\subsection{Preparation and preservation}

The vegetable samples were washed in fresh running water to eliminate dust, dirt, possible parasites or their eggs and then again washed with deionized water. The clean vegetable samples were air-dried and placed in an electric oven at $65^{\circ} \mathrm{C}$ for 72-96 h depending on the sample size. The dried vegetables samples were homogenized by grinding using a ceramic coated grinder used for metal analysis. All soil samples were spread on plastic trays and allowed to dry at ambient temperature for 8 days. The dried samples of soils were ground with a ceramic coated grinder and sieved through a nylon sieve. The final samples were kept in labeled polypropylene containers at ambient temperature before analysis.

\subsection{Digestion and determination}

One gram of dry matter was weighed into $50-\mathrm{ml}$ beaker, followed by the addition of $10 \mathrm{ml}$ mixture of analytical grade acids $\mathrm{HNO}_{3}: \mathrm{HCIO}_{4}$ in the ratio 5:1. The 
digestion was performed at a temperature of about $190{ }^{\circ} \mathrm{C}$ for $1.5 \mathrm{~h}$. After cooling, the solution was made up to a final volume $(30 \mathrm{ml})$ with distilled water in a volumetric flask. The metal $(\mathrm{Pb}, \mathrm{Cd}, \mathrm{Ni}, \mathrm{Co}$, and $\mathrm{Cr})$ concentrations were determined by atomic absorption spectrometry using a VARIAN model AA2407 Atomic Absorption Spectrophotometer (AAS). Analysis of each sample was carried out three times to obtain representative results and the data reported in $\mu \mathrm{g} / \mathrm{g}$ (on a dry matter basis). Statistical differences were performed by Tukey's multiple comparisons test by using Excel Statistics version 4.0 (Esumi Co. Ltd., Tokyo, Japan).

\section{Results and Discussion}

In initial soil, organic matter concentration was $0.49 \%$ and soil $\mathrm{pH}\left(\mathrm{H}_{2} \mathrm{O}\right)$ was 7.3. The concentrations $[\mu \mathrm{g} / \mathrm{g}$ of (dry weight $(\mathrm{DW})]$ of nutrients and heavy metals in initial soil were $260 \mathrm{~N}, 54 \mathrm{P}, 3121 \mathrm{~K}, 478 \mathrm{~S}, 4.04 \mathrm{~Pb}, 0.69 \mathrm{Cd}, 14.4 \mathrm{Ni}$, 11.9 Co, and $21.9 \mathrm{Cr}$. The heavy metal content in initial soil was quite high. The source of soil contamination by heavy metal may be as a result of topdressd-soil, which was collected from Kodda, Joydebpur, Gazipur, a highly industrial effluents polluted area. There is no doubt that heavy metals are also present in soil naturally and non-degradable (Adeyeye, 2005 and Nriagu, 1990). Moreover, the soil may be contaminated with heavy metals as a result of the application of chemical fertilizers. The concentrations $(\mu \mathrm{g} / \mathrm{g})$ of heavy metals in applied fertilizers urea - triple super phosphate (TSP) - muriate of potash (MoP) were 0.0-64.5-0.47 Pb, 0.0-1.01-0.21 Cd, 0.0-28.6-0.60 Ni, 0.0-56.8-2.01 Co, 0.041.4-1.60 Cr, respectively. The results are in good agreement with the data obtained by Zhou et al. (2000). They stated that the main sources of soil pollution by heavy metals are phosphate fertilizers. For example, $\mathrm{Cd}$ is found predominantly in phosphatic fertilizers, resulting from the presence of $\mathrm{Cd}$ as an impurity in all phosphate rocks.

Heavy metals concentrations in plant and soil at different growth stages of vegetables are shown in Figures 1-2. The variation of heavy metals concentrations in soil at different growth stages was non-significant. The concentrations of plant $\mathrm{Pb}, \mathrm{Cd}, \mathrm{Ni}, \mathrm{Co}$, and $\mathrm{Cr}$ increased with the age of the plant up to 40 DAS with the exception of $\mathrm{Cr}$ but the increasing trend was not linear. Chromium concentrations in spinach increased up to 30 DAS and after that, the concentration decreased up to the final harvest at 50 DAS. The metal concentrations of the third harvested (40 DAS) plant samples were higher than those of others with the exception of $\mathrm{Pb}$ concentration in spinach and $\mathrm{Cd}$ in amaranth. The pattern of metal concentration was found different and irregular among the plant species. Only Ni concentration showed the similar trend in the three plant species. Spinach had a higher level of Cd but red amaranth had much lower. Lead concentration was higher in amaranth where as Cd concentration 
was higher in spinach. Cobalt concentration showed the similar trend like $\mathrm{Pb}$. The rate of increasing or slope of metal concentrations was found different at different growth stages. The rate of increasing at 20 DAS to 30 DAS was comparatively low than that at 30 DAS to 40 DAS, except Cr. Cadmium concentrations in spinach, red amaranth and amaranth were increased by 66$182 \%$, 286-534\%, 81-132\%, respectively for the same number of days as $\mathrm{Pb}$. Similarly $\mathrm{Ni}$, Co, and $\mathrm{Cr}$ concentrations in the three vegetables showed increases (in percentage) of metal content, with the exception of $\mathrm{Cr}$ concentration in spinach (49-32\%, decreases).

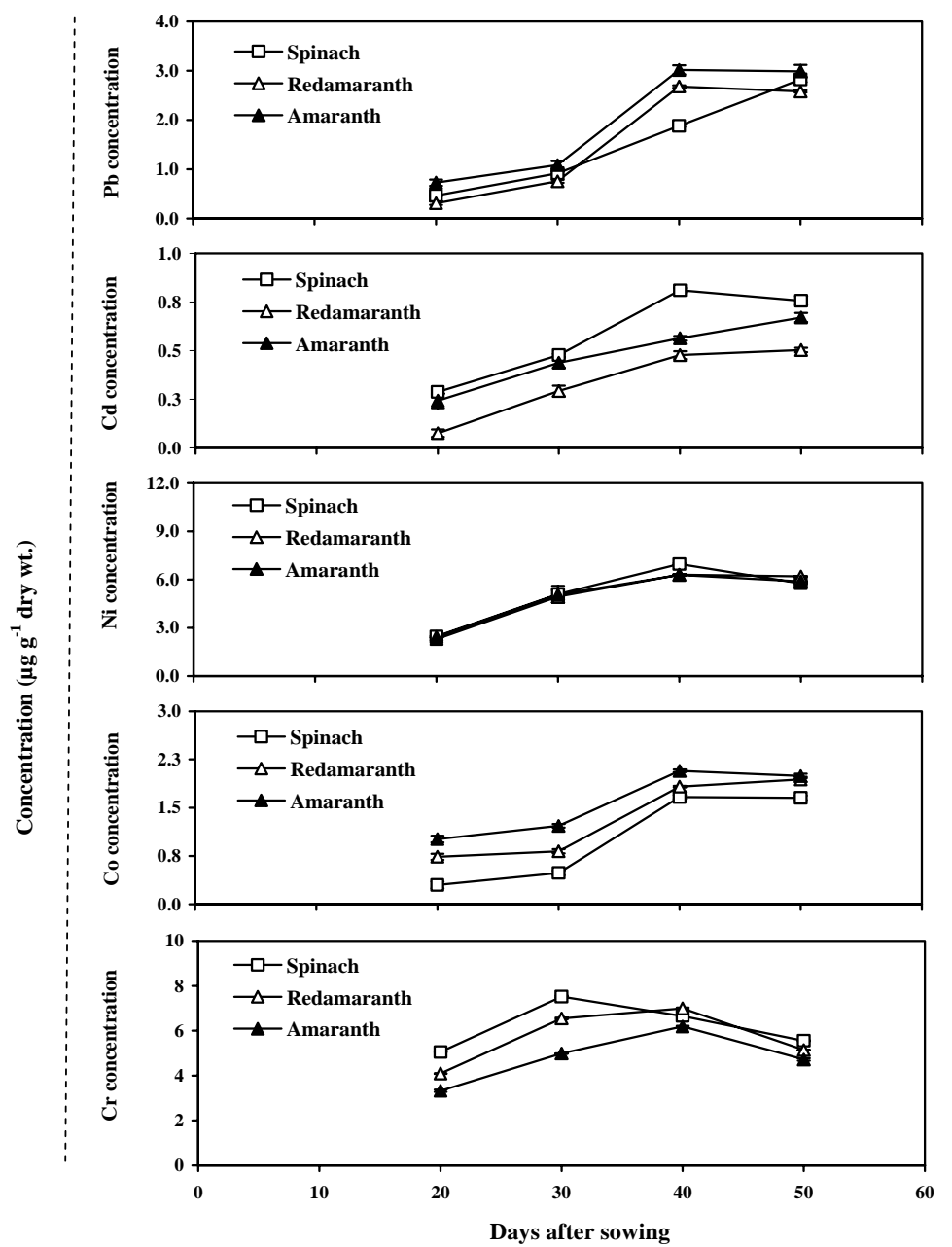

Fig. 1. Pattern of heavy metal concentrations in plant at different growth stages of vegetables 


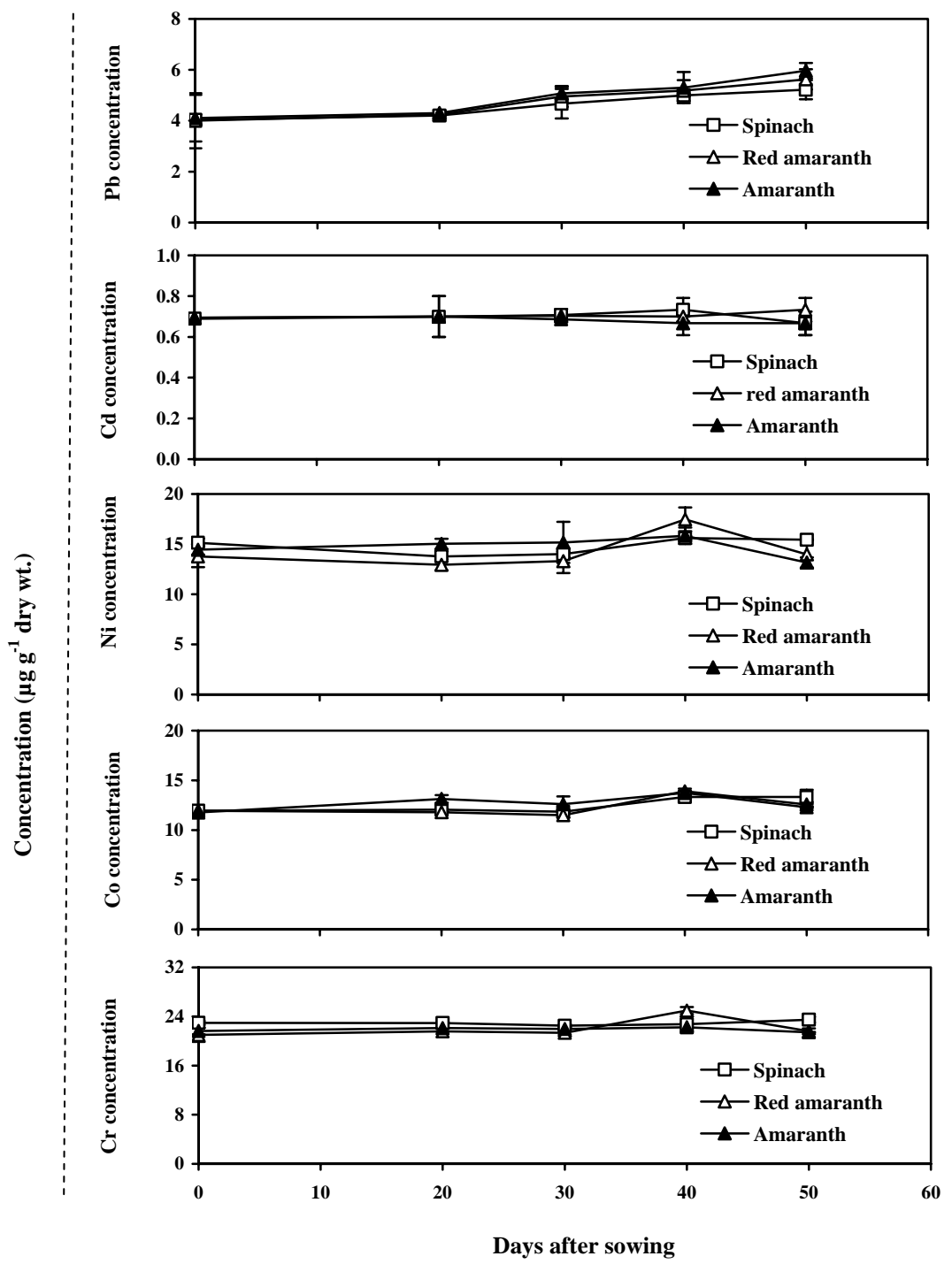

Fig. 2. Pattern of heavy metal concentrations in soil at different growth stages of vegetables

In this experiment, metal content gradually increased at the early growing stages and fall during later stages of growth. The present results are shown to be in good agreement with the result obtained by Oliveira et al. (1994); and Lutts et al. (2004). Mensah et al. (2008) reported that the Pb concentrations in lettuce increased consistently during the period of growth with time. Plant metal content 
varies with time and stage of maturity (Sauerbeck, 1991). However, the magnitude of time dependence of plant metal concentration variations differed among crops and metals according to the study.

The order of level of heavy metals in vegetables was $\mathrm{Cd}<\mathrm{Co}<\mathrm{Pb}<\mathrm{Ni}<\mathrm{Cr}$ (Table 1-2). Heavy metal content by plants can be affected by several factors including metal concentrations in soils, soil $\mathrm{pH}$, cation exchange capacity, organic matter content, types and varieties of plants, and plant age. It is generally accepted that the metal concentration in soil is the dominant factor (Adriano, 1986). Heavy metal availability can also be directly affected by plant itself (Zhang et al., 1991). In the present study, it was observed that the concentration of $\mathrm{Pb}$ in plant was higher than that of $\mathrm{Cd}$. In general, vegetables studied from different areas had a concentration of $\mathrm{Pb}$ higher than that of $\mathrm{Cd}$ (Demi rezen and Aksoy, 2006). The maximum concentration of $\mathrm{Cd}, \mathrm{Ni}$, and $\mathrm{Cr}$ were recorded in spinach, but the highest $\mathrm{Pb}$ and $\mathrm{Co}$ contents were noted in amaranth.

Table 1. Mean Pb, Cd, Ni, Co, and Cr concentration ( \pm , standard deviation) of leafy vegetables.

\begin{tabular}{l|c|c|c|c|c}
\hline \multirow{2}{*}{ Vegetable } & \multicolumn{5}{|c}{ Heavy metal $(\mu \mathrm{g} / \mathrm{g})$} \\
\cline { 2 - 6 } & $\mathrm{Pb}$ & $\mathrm{Cd}$ & $\mathrm{Ni}$ & $\mathrm{Co}$ & $\mathrm{Cr}$ \\
\hline Spinach & $1.52 \pm 0.02 \mathrm{a}$ & $0.583 \pm 0.01 \mathrm{c}$ & $5.07 \pm 0.14$ & $1.03 \pm 0.03 \mathrm{a}$ & $6.20 \pm 0.03 \mathrm{c}$ \\
Red amaranth & $1.58 \pm 0.01 \mathrm{a}$ & $0.337 \pm 0.01 \mathrm{a}$ & $4.93 \pm 0.11$ & $1.33 \pm 0.03 \mathrm{~b}$ & $5.70 \pm 0.01 \mathrm{~b}$ \\
Amaranth & $1.95 \pm 0.05 \mathrm{~b}$ & $0.478 \pm 0.02 \mathrm{~b}$ & $4.92 \pm 0.07$ & $1.57 \pm 0.03 \mathrm{c}$ & $4.81 \pm 0.01 \mathrm{a}$ \\
\hline
\end{tabular}

Values in a column followed by a common letter are not significantly different at $P<0.01$.

Table 2. Mean Pb, Cd, Ni, Co and Cr concentration ( \pm , standard deviation) of soils where the vegetables grown.

\begin{tabular}{l|c|c|c|c|c}
\hline \multirow{2}{*}{ Vegetable } & \multicolumn{5}{|c}{ Heavy metal $(\mu \mathrm{g} / \mathrm{g})$} \\
\cline { 2 - 6 } & $\mathrm{Pb}$ & $\mathrm{Cd}$ & $\mathrm{Ni}$ & $\mathrm{Co}$ & $\mathrm{Cr}$ \\
\hline Spinach & $4.77 \pm 0.23$ & $0.70 \pm 0.01$ & $14.7 \pm 0.17$ & $12.6 \pm 0.19$ & $22.9 \pm 0.34$ \\
Red amaranth & $5.00 \pm 0.20$ & $0.71 \pm 0.03$ & $14.4 \pm 0.61$ & $12.4 \pm 0.14$ & $22.4 \pm 0.07$ \\
Amaranth & $5.16 \pm 0.15$ & $0.68 \pm 0.02$ & $14.8 \pm 0.47$ & $12.9 \pm 0.30$ & $21.9 \pm 0.27$ \\
\hline
\end{tabular}

The result indicated that there was significant difference $(P<0.01)$ in mean heavy metal content in the three vegetable species. The result showed significantly higher level of $\mathrm{Pb}$ concentration in amaranth compared to spinach and red amaranth. Spinach exhibited significantly higher levels of $\mathrm{Cd}$ and $\mathrm{Cr}$ than the other vegetables. The difference in level of heavy metal contamination between spinach and amaranth species was due to their morpho-physiological differences in terms of heavy metal content, exclusion, accumulation, foliage 
deposition and retention efficiency (Carlton-Smith and Davis, 1983). Cadmium concentration mostly appeared in leafy vegetables and was in order of spinach $>$ amaranth $>$ red amaranth. The level of $\mathrm{Cd}$ in the samples analyzed in this study was ranged from 0.34 to $0.58 \mu \mathrm{g} / \mathrm{g}$ of Dw. The Cd concentration of vegetables in this study was in agreement with the findings of Yusuf et al., (2003) who found Cd concentration in leafy vegetables to be 0.09 ( $\mu \mathrm{g} / \mathrm{g}$ of DW). Singh and Kumar (2006) reported that $\mathrm{Pb}$ and $\mathrm{Cd}$ content in spinach ranged between 1.7 and 7.0 and 2.0 and $7.1 \mu \mathrm{g} / \mathrm{g}$ DW, respectively. The three vegetables did not differ significantly in $\mathrm{Ni}$ content. Cobalt showed similar trend as of $\mathrm{Pb}$. The $\mathrm{Cr}$ concentration in vegetables from this study were higher than those recorded by Nagajyoti et al. (2008) who found Cr concentration in five leafy vegetables ranging between 0.89 to 1.08 ( $\mu \mathrm{g} / \mathrm{g}$ of DW). Haiyan and Stuanes (2003) reported that the $\mathrm{Cr}$ content in the vegetables grown in controlled area ranged from 0.4 to 2.7 ( $\mu \mathrm{g} / \mathrm{g}$ of DW).

Table 3. Correlations between heavy metal content ${ }^{\S}$ in soils and in vegetables $\left(\S=\mu \mathrm{g} / \mathrm{g},{ }^{*}=p<0.05, * *=p<0.01, \mathrm{~ns}=\right.$ non significant $)$

\begin{tabular}{l|c|c|c|c|c}
\hline \multirow{2}{*}{ Vegetable } & \multicolumn{5}{|c}{ Heavy metal } \\
\cline { 2 - 6 } & $\mathrm{Pb}$ & $\mathrm{Cd}$ & $\mathrm{Ni}$ & $\mathrm{Co}$ & $\mathrm{Cr}$ \\
\hline Spinach & $0.944 \mathrm{~ns}$ & $0.965^{*}$ & $0.679 \mathrm{~ns}$ & $0.999^{* *}$ & $0.955^{*}$ \\
Red amaranth & $0.930 \mathrm{~ns}$ & $0.957^{*}$ & $0.670 \mathrm{~ns}$ & $0.772 \mathrm{~ns}$ & $0.948 \mathrm{~ns}$ \\
Amaranth & $0.819 \mathrm{~ns}$ & $0.988^{*}$ & $0.911 \mathrm{~ns}$ & $0.693 \mathrm{~ns}$ & $0.700 \mathrm{~ns}$ \\
\hline
\end{tabular}

Table 4. Transfer factor ( \pm , standard deviation) of $\mathrm{Pb}, \mathrm{Cd}, \mathrm{Ni}, \mathrm{Co}$ and $\mathrm{Cr}$ for the soils to vegetables species.

\begin{tabular}{l|c|c|c|c|c}
\hline \multirow{2}{*}{ Vegetable } & \multicolumn{5}{|c}{ Heavy metal } \\
\cline { 2 - 6 } & $\mathrm{Pb}$ & $\mathrm{Cd}$ & $\mathrm{Ni}$ & $\mathrm{Co}$ & $\mathrm{Cr}$ \\
\hline Spinach & $0.320 \pm 0.016$ & $0.831 \pm 0.015$ & $0.345 \pm 0.008$ & $0.081 \pm 0.002$ & $0.271 \pm 0.005$ \\
Red amaranth & $0.317 \pm 0.014$ & $0.475 \pm 0.011$ & $0.343 \pm 0.021$ & $0.107 \pm 0.003$ & $0.255 \pm 0.001$ \\
Amaranth & $0.379 \pm 0.006$ & $0.703 \pm 0.018$ & $0.332 \pm 0.015$ & $0.122 \pm 0.002$ & $0.219 \pm 0.003$ \\
\hline
\end{tabular}

The variation of mean concentrations of the metals in soils at different growth stages of three vegetables plots was non-significant. The $\mathrm{Pb}, \mathrm{Cd}$, and $\mathrm{Ni}$ concentrations in soils from this study were found lower than those obtained by Demi rezen and Aksoy (2006), who found the concentrations ( $\mu \mathrm{g} / \mathrm{g}$ ) of $\mathrm{Pb}, \mathrm{Cd}$, and $\mathrm{Ni}$ to be $95,1.83$ and 29, respectively, in the soils of non-contaminated rural area. Nickel and $\mathrm{Cr}$ showed higher values in soils compared to $\mathrm{Pb}$ and $\mathrm{Cd}$ contents. The $\mathrm{Cr}$ concentration in soils from this study was much lower than those obtained by Haiyan and Stuanes (2003) who found Cr concentration to be 
approximately $108(\mu \mathrm{g} / \mathrm{g}$ DW). The order of heavy metal level in soil was $\mathrm{Cd}<\mathrm{Pb}<\mathrm{Co}<\mathrm{Ni}<\mathrm{Cr}$. Heavy metal concentrations values are higher in soil samples compared to vegetables samples. Demi rezen and Aksoy (2006) also reported that the level of heavy metals in vegetables were generally lower than the soil samples. Such results might be attributed due to root activity, which seems to act as a barrier for translocation of metals (Davies and White, 1981; Yusuf et al., 2003). Heavy metal absorption is governed by soil characteristics, such as $\mathrm{pH}$ and organic matter content. High levels of heavy metals in soils do not always indicate similar high concentrations in plants. The extent of accumulation and toxic level depend on the plant and heavy metal species (Alloway, 1996).

In order to ascertain probable relationship between $\mathrm{Pb}, \mathrm{Cd}, \mathrm{Ni}$, $\mathrm{Co}$, and $\mathrm{Cr}$ content of soils and vegetables, correlations were calculated. The results showed (Table 3) positive correlation between metal concentration in soils and vegetables, and the correlation varied widely. The highest correlation between soil-plant was found with Cd, while the lowest was with Ni. The relationship between soil and plant depend on available forms of metal ions in soil.

Transfer factor (TF) of different heavy metals from soil to vegetables was calculated as the ratio between the concentrations of heavy metals in vegetables and their respective concentration in soils (Table 4). The TF is one of the key components of human exposure to metals through the food chain. In all three vegetables an opposite trend in $\mathrm{TF}$ was observed $(\mathrm{Cd}>\mathrm{Ni}>\mathrm{Pb}>\mathrm{Cr}>\mathrm{Co})$ as of metal concentration in vegetable. The mobility of metals from soil to plant is a function of the physical and chemical properties of the soil and of vegetable species, and is altered by innumerable environmental and human factors (Zurera et al., 1987). The highest TF values $0.831,0.475$, and 0.703 were found for $\mathrm{Cd}$ in spinach, red amaranth and amaranth, respectively. This might be due to higher mobility of $\mathrm{Cd}$ with a natural occurrence in soil (Alam et al., 2003), and the low retention of Cd (II) in the soil than other toxic cations (Lokeshwari and Chandrappa, 2006). The result also supports the findings that accumulation of $\mathrm{Pb}$ and $\mathrm{Ni}$ is comparatively less than that of Cd in plants (Olaniya et al., 1998).

The accumulation concentration of $\mathrm{Cd}$ and $\mathrm{Cr}$ was higher and that of $\mathrm{Pb}$ and $\mathrm{Ni}$ was lower than the maximum allowable level set by WHO (Fig. 3). The allowable level of $\mathrm{Pb}, \mathrm{Cd}, \mathrm{Ni}$, and $\mathrm{Cr}$ as set by the $\mathrm{WHO}$ were 2.0, 0.02, 10.0 and $1.30 \mu \mathrm{g} / \mathrm{g}$, respectively (Lone et al., 2003). However, metal concentration of vegetables in this study was lower than the maximum allowable level for $\mathrm{Pb}, \mathrm{Cd}$, $\mathrm{Ni}$, and $\mathrm{Cr}(2.5,1.5,5.0$, and $20 \mu \mathrm{g} / \mathrm{g} \mathrm{DW}$, respectively) as set in the Prevention of Food Adulteration Act (PFA), 1954, India (Lokeshwari and Chandrappa, 2006). 


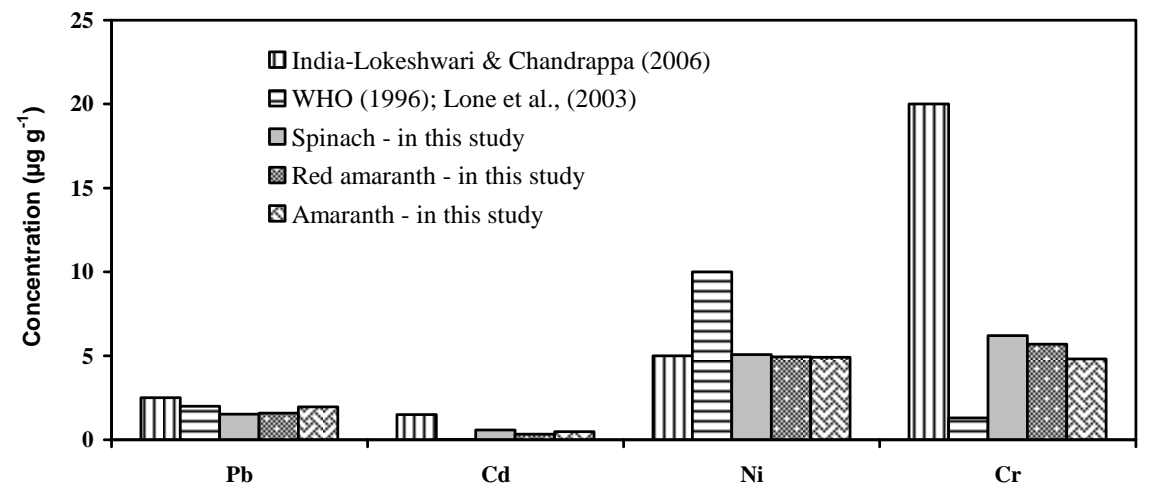

Fig. 3. Total concentrations of metal in vegetables and maximum allowable limits

\section{Conclusion}

Heavy metal content in different leafy vegetables varies significantly. The content varies with time of harvesting and stage of maturity of crops. The $\mathrm{Cd}$ and $\mathrm{Cr}$ contents in leafy vegetables in this study were detected higher while $\mathrm{Pb}$ and Ni were within the permissible limits as per the WHO standard but all the metals were within the maximum allowable level as per PFA, 1954, India. The magnitude of time dependence of plant metal concentration variations differed among crop species and metals. Further research is needed to obtain more specific information about the effect of age of the plants on accumulation and distribution of the heavy metal in the different plant parts, variations in uptake between different plant species, cropping history and fertilization.

\section{References}

Adeyeye, E.I., 2005. Trace metals in soils and plants from Fadama farms in Ekiti state, Nigeria. Bulletin of Chemical Society of Ethiopia 19: 23-24.

Adriano, D.C., 1986. Trace elements in the terrestrial environment. Springer-Verlag Inc.: New York. pp. 1- 45.

Akinola, M.O., Njoku, K.L., Ekeifo, B.E., 2008. Determination of lead, cadmium and chromium in the tissue of an economically important plant grown around a textile industry at Ibeshe, Ikorodu area of Lagos State, Nigeria. Advances in Environmental Biology 2(1): 25-30.

Alam, M.G.M., Snow, E.T., Tanaka, A., 2003. Arsenic and heavy metal contamination of vegetables grown in Samta village, Bangladesh. The Science of the Total Environment 308: 83-96.

Alloway, B.J., 1996. Heavy metal in soils. Halsted Press, John Wiley \& Sons Inc., London. 
Bigdeli, M., Seilsepour, M., 2008. Investigation of metals accumulation in some vegetables irrigated with waste water in Shahre Rey-Iran and toxicological implications. American- Eurasian Journal of Agricultural \& Environmental Sciences 4 (1): 86-92.

Bowen, H. J. M., 1979. Environmental Chemistry of the Elements, p. 237, Academic Press, London.

Buchaver, M. J., 1973. Contamination of soil and vegetation near zinc smelter by zinc, cadmium, copper and lead. Environmental Science \& Technology 7: 131-135.

Carlton-Smith, C. H., Devis, R. D., 1983. Comparative uptake of heavy metals by forage crops grown on sludge-treated soils. Proc. Int. Conf. Heavy Metals in the Environment. Vol. 1, Heidelberg, CEP consultants Ltd., Edinburgh, U.K. pp 3933.

Chatterjee, J., Chatterjee, F., 2000. Phytotoxicity of chromium, cobalt and copper in cauliflower. Environmental Pollution 109: 69-74.

Davies, B.E., White, H.M., 1981. Trace element in vegetables grown on soils contaminated by base metal mining. Journal of Plant Nutrition 3: 387-396.

Demi rezen, D., Aksoy, A., 2004. Accumulation of heavy metals in Typha angustifolia (L.) and Potamogeton pectinatus (L.) Living in Sultan Marsh (Kayseri, Turkey). Chemosphere 56: 685-696.

Demi rezen, D., Aksoy, A., 2006. Heavy metal levels in vegetables in turkey are within safe limits for $\mathrm{Cu}, \mathrm{Zn}, \mathrm{Ni}$ and exceeded for $\mathrm{Cd}$ and Pb. Journal of Food Quality 29: 252-265.

Fergusson, J.E., 1990. The heavy elements: chemistry, environmental impact and health effects. Pergamin Press, Oxford. p.382-399.

Goyer, R.A., 1996. Toxic and essential metal interaction. Annual Review of Nutrition 17: 37-50.

Haiyan, W., Stuanes, A., 2003. Heavymetal pollution in air-water-soil-plant system of zhuzhou city, hunan province, china. Water, Air, and Soil Pollution 147: 79-107.

Lokeshwari, H., Chandrappa, G.T., 2006. Impact of heavy metal contamination of Bellandur Lake on soil and cultivated vegetation. Current Science 91(5), 1-6.

Lone, M.I., Saleem, S., Mahmood, T., Saifullah, K., Hussain, G., 2003. Heavy metal contents of vegetables irrigated by sewage/tubewell water. International. Journal of Agriculture \& Biology 5(4), 533-535.

Lubben, S., Sauerberck, D., 1991. The uptake and distribution of heavy metals by spring wheat. Water, Air, and Soil Pollution 57/58: 239-247.

Lutts, S., Lefe`vre, I., D., Delpe're'e, C., Kivits, S., Dechamps, C., Robledo, A., Correal E., 2004. Heavy Metal Accumulation by the Halophyte Species Mediterranean Saltbush. Journal of Environmental Quality 33: 1271-1279.

Ma, Q. Y., Traina, S. J., Logan, T. J., 1994. Effect of aqueous Al, Cd, Fe(II), Ni and Zn on $\mathrm{Pb}$ immobilization by hydroxyapatite. Environmental Science \&. Technology 28(7): 1219-1228.

Markert, B., 1993. Plant as Biomonitors: Indicators for Heavy Metals in the Terrestrial Environment. (B. Markert, ed.), VCH Weinheim, New York /Basel /Cambridge. 
Mensah, E., Allen, H.E., Shoji, R., Odai, S. N., Kyei-Baffour, N., Ofori, E., Mezler, D., 2008. Cadmium (Cd) and lead $(\mathrm{Pb})$ concentrations effects on yields of some vegetables due to uptake from irrigation water in Ghana. International Journal of Agricultural Research 3(4): 243-251.

Msaky, J.J., \& Calvert, R., 1990. Adsorption behavior of copper and zinc in soils: influence of $\mathrm{pH}$ on adsorption characteristics. Soil Science 150(2): 513-522. [doi:10.1097/000 10694-199008000-00004]

Nagajyoti, P.C., Dinakar, N., Prasad, T.N.V.K.V., Suresh, C., Damodharam, T., 2008. Heavy metal toxicity: Industrial Effluent Effect on Groundnut (Arachis hypogaea L.) Seedlings. Journal of Applied Sciences Research 4(1): 110-121.

Nriagu, J.O., 1990. Global metal pollution: Poisoning the biosphere. Environment Envtar, 32(9): 7-11, 28-33.

Okonkwo, N.C., Igwe, J.C., Onwuchekwa, E.C., 2005. Risk and health implications of polluted soils for crop production. African Journal of Biotechnology 4(13): 15211524.

Olaniya, M.S., Sur, M.S., Bhide, A.D., Swarnakar, S.N., 1998. Heavy metal pollution of agricultural soil and vegetation due to application of municipal solid waste - A case study. Indian Journal of Environment \& Health 40: 160-168.

Oliveira J. A. De., Oliva, M. A., Cambraia, J., Venegas, V. H. A., 1994. Absorption, accumulation and distribution of cadmium by two soybean cvs. Revista Brasileira de Fisiologia Vegetal 6(2): 91-95.

Sauerbeck, D. R., 1991. Plant, element and soil properties governing plant uptake and availability of heavy metals derived from sewage sluge. Water, Air, and Soil Pollution 227: 57-58.

Sharma, V.K., Kansal, B.D., 1986. Heavy metal contamination of soils and plants with sewage irrigation. Pollution Research 4: 86-91.

Singh, S., \& Kumar, M., 2006. Heavy metal load of soil, water and vegetables in periurban delhi. Environmental Monitoring and Assessment 120: 79-91.

Yargholi, B., Azimi, A. A., 2008. Investigation of Cadmium absorption and accumulation in different parts of some vegetables. American-Eurasian Journal of Agricultural \& Environmental Sciences 3(3): 357-364.

Yusuf, A.A., Arowolo, T.A., Bamgbose, O., 2003. Cadmium, copper and nickel levels in vegetables from industrial and residential areas of Lagos City, Nigeria. Food \& Chemical Toxicology 41: 375-378.

Zhang, F., Romheld,V., Marschner, H., 1991. Release of zinc mobilizing root exudates in different plant species as affected by Zn nutritional status. Journal of Plant Nutrition 14: 675-686.

Zhou, Z., Fan, Y., Wang, M., 2000. Heavy metal contamination in vegetables and their control in China. Food Reviews International 16(2): 239-255.

Zurera, G., Estrada, B., Rincon, F., Pozo, R., 1987. Lead and cadmium contamination levels in edible vegetables. Bull. Environmental Contamination and Toxicology 38: 805-812. 